\title{
Using videos to improve elementary students' listening comprehension in foreign languages and informatics center of PPC II
}

\author{
Duong Thuc Phuong ${ }^{1 *}$ \\ ${ }^{1}$ Ho Chi Minh City Open University, Vietnam \\ *Corresponding author: duongthucphuongnn@gmail.com
}

\begin{tabular}{|c|c|}
\hline ARTICLE INFO & ABSTRACT \\
\hline $\begin{array}{l}\text { DOI: 10.46223/HCMCOUJS. } \\
\text { soci.en.8.2.280.2018 }\end{array}$ & $\begin{array}{l}\text { The current study aimed to examine the impact of using } \\
\text { videos on students' listening learning and their attitudes towards } \\
\text { using videos in listening learning. The study was conducted with } \\
71 \text { participants in two groups in Foreign Languages and } \\
\text { Informatics Center of PPC II (People's Police College II). The } \\
\text { first group of } 35 \text { students worked with } 10 \text { audio recordings, while }\end{array}$ \\
\hline Received: October $30^{\text {th }}, 2018$ & the second group of 36 students worked with 10 videos in a $10-$ \\
\hline Revised: November $31^{\text {st }}, 2018$ & week treatment. The listening materials for both groups had the \\
\hline Accepted: December $6^{\text {th }}, 2018$ & $\begin{array}{l}\text { same scripts. Although there was no statistically significant } \\
\text { difference in the pre-test between the two groups, the statistics of } \\
\text { the post-test shows that the EG (experimental group) } \\
\text { outperformed the CG (control group) in listening comprehension. } \\
\text { Besides, the data from the questionnaire indicate that the } \\
\text { participants had positive attitudes towards using videos in }\end{array}$ \\
\hline $\begin{array}{l}\text { Keywords: } \\
\text { attitudes, listening } \\
\text { comprehension, videos }\end{array}$ & $\begin{array}{l}\text { listening learning. These findings could be explained by visual } \\
\text { elements of the teaching materials. Therefore, it was suggested } \\
\text { to use videos in listening learning to promote students' listening } \\
\text { comprehension. }\end{array}$ \\
\hline
\end{tabular}

\section{Introduction}

\subsection{Research problem}

In recent years, listening has gradually become a dominant skill in language instruction in colleges and universities. In the context of the Foreign Languages and Informatics Center in PPCII, listening skills are also tested in the final examination. After two school years from 2014 to 2016, a large number of the (non-English major) students failed the listening exams. Besides, there has been some research on using videos as a kind of listening materials. Among the few research, some prove that practicing listening with videos enhances students' listening comprehension (Herron, York, Corrie, \& Cole, 2006; Mesri, 2011; Nguyen, 2012; Woottipong, 2014); some others point out that videos promote students' positive attitudes towards listening learning (Chiang, 1996; Nguyen, 2012; Oddone, 2011; Woottipong, 2014). However, those studies revealed some shortcomings. First, only a few studies (Nguyen, 2012; Woottipong, 2014) focus on both the effects of using videos on students' listening comprehension and their 
attitudes towards using videos in listening learning, making it hard to explain the relationship between using videos and students' improved performance, as students' listening performance could partly be influenced by their attitudes towards listening learning (Ellis, 2015; Jafari, 2009; Karahan, 2007). Second, in other studies (Mesri, 2011; Nguyen, 2012), the listening materials for CG and EG are different in terms of content, vocabulary, and length, so the difference in the students' listening comprehension may also be due to factors other than videos. Regarding research methods, some experiments (Chiang, 1996; Oddone, 2011; Woottipong, 2014) are conducted with only one group of participants, so there is not enough convincing evidence that videos are better than audio materials.

Therefore, the current study aimed at overcoming the shortcomings of the previous studies by investigating the effects of using videos to practice listening on elementary students' listening comprehension and exploring the students' attitudes towards using this type of materials in listening learning, with two groups CG and EG. The listening materials for the two groups had the same content, vocabulary and length. This study is expected to suggest a new type of listening materials to students and teachers in Foreign Languages and Informatics Center of PPC II in order to improve elementary students' listening skills.

\subsection{Research questions and research hypothesis}

In order to reach its aim, this study is guided by the two following questions:

1. How do elementary students who are taught listening with videos differ from those who are taught listening with audio materials in terms of listening comprehension?

2. What are elementary students' attitudes towards using videos in listening learning?

Based on research question 1, the following hypothesis was designed: students in Foreign Languages and Informatics Center of PPCII who listen with videos will improve their listening comprehension more than those who listen with audio materials.

\section{Literature review}

\subsection{Nature of listening}

There have been several stances of listening so far and they are expressed in different ways. Brownell (2016) defines listening as a process of receiving, constructing meaning and responding to not only spoken messages but also nonverbal ones. Schmitt (2010) asserts that listening is a process of making sense of spoken language due to sounds and visual input, and with the assistance of our relevant background knowledge and listening context, so listening is not considered as a passive process, but it is an active one (Rumelhart, 1977).

\subsection{Videos}

Recently, videos are more widely used as listening materials in the classroom, but it seems that there is no official definition of videos, there are only a few explanations of videos. According to Canning-Wilson (2000, p. 1), videos are "the selection and sequence of messages in an audio-visual context". Ilin, Kutlu, and Kutluay (2013) consider videos as "a widespread multimedia tool that has both visual and audio content" (p. 273). In other words, videos are a multimedia tool consisting of visual and audio elements, and they can be selected and used as instructional materials in classroom. Considering the purpose of use, videos are categorized into two types: (1) authentic videos and (2) educational videos. 
Videos which are considered as authentic ones are made by and for native language speakers (Bacon \& Finnemann, 1990). They help expose learners to real communication. They can be video clips available on the Internet, films, songs, TV programs, and cartoons. In addition, authentic videos are not produced for learning and teaching (Hammer, 1991; Nunan, 1999), so they are not complete units for learning (Oddone, 2011). Thus, it takes teachers time to select videos and design classroom activities which are suitable for students' levels and lesson objectives. Educational videos are designed by educators specifically for the classroom with teachers' guide, and the content meets requirements of curricula and educational standards. Thus, teaching and learning processes are much more facilitated than using authentic videos (Stohlman, 2009). Educational videos may be films, educational television programs, or broadcasts, which are designed specifically as supplemental classroom materials (Cruse, 2007; Intajuck, 2010).

There are several reasons for using videos. The first reason is that videos can facilitate students' listening comprehension due to visual clues such as gestures, facial expressions, dress, and some details of the setting. Second, some research proves that students have positive attitudes toward using videos in listening learning (Ismaili, 2013; Woottipong, 2014). Another reason is that authentic videos help students increase not only listening comprehension but also cultural understanding (Roh, 2011). However, selecting videos appropriate to students' interests and levels is an extremely significant job of teachers to enhance listening learning and teaching. Teachers should seriously take these things into account, including purpose and expectation for watching, video content, subtitle, and video quality (Canning-Wilson, 2000; Denning, 2010).

\subsection{Learners' attitudes}

Attitudes are internal states that consist of three components feelings, beliefs and behavior tendencies toward something or somebody (Baron \& Byrne, 1984). Feelings or affective component is emotional evaluation (liking or disliking) towards an object which is called attitude object. Beliefs or cognitive component is an evaluation that a person has about the attitude object. And the last component is behavior tendencies or behavioral components. Behavior tendencies are a particular way a person tends to act towards a person or object. The three components together form attitudes, but they may be consistent or inconsistent with each other.

Regarding the influence of attitudes on learners' behaviors, Karahan (2007) and Ellis (2015) argue that positive attitudes create students' positive tendencies towards learning English. In a study, Jafari (2009) stated that students get bored with listening lessons when they have no interest in learning; as a result, they do learn passively, and this leads students to less progress. Besides, a lot of research proves that attitudes somewhat influence learners' achievement in learning a language. Gardner and Lambert (1972) report that when students have positive attitudes towards a lesson, they will more enjoy and gain more knowledge and skills.

\subsection{Previous studies of using videos on students' listening learning}

Up till now, several studies have been implemented on the impacts of using videos in language listening classes on learners' listening abilities, and their findings will be taken into account to make theoretical background for the current study. 
A notable study is the one by Herron et al. (2006). Twenty-seven students at the intermediate level were selected and assigned into two groups; one group was exposed to a textbased instructional curriculum with audio program, the other to a story-based video instructional package curriculum during 15 weeks. The pre-test and post-test scores showed that the group working with story-based videos more significantly improved their listening than the other. In Mesri's (2011) study with 3 experimental groups of 90 Iranian EFL students at intermediate levels, the first group received tape recorders, the second group received pictures and the last one received videos for listening lessons in the same textbook. The score of the post-test showed that there was a statistically crucial effect of videos on students' listening comprehension compared with pictures and tape-recorders.

In addition to the impact of videos on students' listening performance, some researchers investigate learners' attitudes towards using videos in listening to lessons. A study by Chiang (1996) carried out with 96 freshmen for two months shows that films made the lessons more enjoyable. In this vein, a study on using videos from YouTube and websites in the CLIL classroom was undertaken by Oddone (2011) with 30 elementary students in a secondary vocational school in North-West Italy. They were taught with videos in English related to their majors. By observing students' participation during the course, the researcher concluded that using authentic videos boosted students' motivation.

Some other researchers have conducted investigations into both the impact of using videos on learners' listening comprehension and their attitudes simultaneously. Woottipong (2014) conducted an experimental course with a group of 41 English major freshmen at Thaksin University, Thailand over 20 teaching periods. The results showed that learners' listening abilities increasingly improved and they showed interest in videos. Additionally, Nguyen (2012) undertook a study with 2 groups of elementary sophomores in Kien Giang TechnologyEconomics College. The first group had opportunities to study listening with authentic videos; whereas the second group worked with audio recordings in the textbook. Her study explained that students' listening comprehension was significantly improved due to using authentic videos, and the students also showed their positive attitudes towards using videos in listening learning.

The previous studies confirm the positive impact of using videos on students' listening comprehension and their positive attitudes towards using videos in listening learning. However, they reveal some gaps (see section 1.1.) that the current study aimed to bridge.

\section{Methodology}

\subsection{Study design}

The current study was undertaken with a quasi-experimental design. According to Creswell (2012), in a quasi-experiment, intact groups, nonrandom sampling and nonrandom assignment were utilized.

\subsection{Research site and participants}

The participants of the study included 71 elementary students in two intact classes in Foreign Languages and Informatics Center of PPC II, Ho Chi Minh City. The two classes were assigned as a CG (35 students) and an EG (36 students). Most of the participants were male (68 
males and 3 females), aged from 20 to 23. They have studied English for around 8 years, and they had a little time practicing listening outside class.

\subsection{Instruments and measurement}

In order to answer the research questions, two types of instruments were used to collect data including tests and questionnaires. All of the instruments were piloted at least once.

The pre-test and post-test were taken from a book of test papers namely Cambridge Key English Test 1 (Cambridge University Press, 2003). Each test had 25 items. In order to score the tests, the researcher applied a 10-point scale, and each item counted 0.4 points.

The first questionnaire including six simple questions was used to get information on participants' general characteristics regarding their age, gender, years of learning English, time practicing listening outside class.

The second questionnaire including 14 items aimed to explore students' attitudes towards using videos in listening learning. The questionnaire was organized into three scales measuring three components of attitudes: Scale 1 (items 1-4) about students' feelings on using videos in listening learning, Scale 2 (items 5-11) about students' beliefs about using videos in listening learning, and Scale 3 (items 12-14) about students' behavior tendencies towards listening learning. Likert five-point scale was used. The five-point scale was ranged from the lowest to the highest, 1-strongly disagree, 2-disagree, 3-uncertain, 4-agree, 5-strongly agree. However, after checking the internal consistency of the 3 scales, items 10 and 11 were removed. As a result, only the 12 remaining items of the questionnaire were used for further analysis.

\subsection{Materials}

The materials for the experiment included the audio and video versions of 10 listening sections taken from the coursebook Life A1-A2 by Hughes, Stephenson, and Dumette (2016) Vietnam edition. Both versions had the same scripts, and activities were available in the coursebook. However, the researcher adapted some while-viewing activities to ensure that they were appropriate to the CG.

\subsection{Procedure}

The study consisted of three phases. First, the first questionnaire and the pre-test were administered to both CG and EG. After that, the 10-week treatment was implemented. The CG learned listening with audio materials, whereas the EG with videos. Finally, the post-test was administered to both groups and the second questionnaire to the EG only.

\subsection{Data analysis}

The data were analyzed using descriptive statistics and inferential statistics. Regarding inferential statistics, the normality of the data set was tested and it was found that the data set did not have a normal distribution; thus, nonparametric tests including Mann-Whitney $U$ test and Wilcoxon Signed Ranks Test was used.

\section{Results and discussion}

\subsection{Impact of using videos on students' listening comprehension}

Performance of the CG and EG on the pre-test and post-test 
Table 1 shows that there is a difference in the mean scores of the pre-test between the two groups ( $M=4.3, S D=1.3$, for the $C G$; and $M=4.1, S D=1.4$ for the EG). Besides, there is a difference in the mean scores of the post-test between the two groups $(M=4.9, S D=1.6$ for the $\mathrm{CG}$; and $M=5.6, S D=1.6$ for the EG).

\section{Table 1}

Descriptives of the CG and EG's pre-test and post-test

\begin{tabular}{|c|cc|c|c|c|c|c|}
\hline & & & Minimum & Maximum & Mean & Median & $\begin{array}{c}\text { Standard } \\
\text { Deviation }\end{array}$ \\
\hline \multirow{2}{*}{ Pre-test } & \multirow{2}{*}{ Group } & CG & 2.8 & 8.4 & 4.3 & 4.0 & 1.3 \\
& & EG & 2.8 & 8.0 & 4.1 & 3.6 & 1.4 \\
\hline \multirow{2}{*}{ Post-test } & \multirow{2}{*}{ Group } & CG & 3.2 & 9.2 & 4.9 & 4.8 & 1.6 \\
& & EG & 3.2 & 9.2 & 5.6 & 5.6 & 1.6 \\
\hline
\end{tabular}

Source: The researcher's data analysis

\section{Comparison between the CG's and EG's Pre-test}

With statistics of Mann-Whitney Test (Table 2), the significance value is .398, which is greater than .05; so there is no statistically significant difference between the CG $(M d n=4.0)$ and the EG $(M d n=3.6)$ (see Table 1) in the pre-test.

\section{Table 2}

Mann-Whitney U test for the scores of the CG and EG's pre-test

\section{Ranks}

\begin{tabular}{|c|c|c|c|c|}
\hline & Group & $\mathbf{N}$ & Mean Rank & Sum of Ranks \\
\hline \multirow{3}{*}{ Pretest } & $\mathrm{CG}$ & 35 & 38.07 & 1332.50 \\
\hline & EG & 36 & 33.99 & 1223.50 \\
\hline & Total & 71 & & \\
\hline
\end{tabular}

\begin{tabular}{|l|r|}
\hline \multicolumn{2}{|c|}{ Test Statistics } \\
\hline \multicolumn{2}{|c|}{ Pretest } \\
\hline Mann-Whitney U & 557.500 \\
Wilcoxon W & 1223.500 \\
Z & -.844 \\
Asymp. Sig. (2-tailed) & .398 \\
\hline
\end{tabular}

a. Grouping Variable: Group

Source: The researcher's data analysis

\section{Comparison between the CG's pre-test and post-test}

The results of Wilcoxon Signed Ranks Test (.sig=.093) in Table 3 show that there is no statistically significant difference in the pre-test $(M d n=4.0)$ and post-test $(M d n=4.8)$ (see Table 1) of the CG. 


\section{Table 3}

Wilcoxon Signed Ranks Test for the CG before and after the treatment

Ranks

\begin{tabular}{|l|l|c|c|c|}
\hline & N & Mean Rank & Sum of Ranks \\
\hline Posttest - Pretest & $\begin{array}{l}\text { Negative } \\
\text { Ranks }\end{array}$ & $10^{\mathrm{a}}$ & 15.10 & 151.00 \\
& $\begin{array}{l}\text { Positive } \\
\text { Ranks }\end{array}$ & $20^{\mathrm{b}}$ & 15.70 & 314.00 \\
& Ties & $5^{\mathrm{c}}$ & & \\
& Total & 35 & & \\
\hline
\end{tabular}

a. Posttest $<$ Pretest

b. Posttest $>$ Pretest

c. Posttest $=$ Pretest

\section{Test Statistics}

\begin{tabular}{|l|c|}
\hline & Posttest - Pretest \\
\hline $\mathrm{Z}$ & $-1.682^{\mathrm{b}}$ \\
Asymp. Sig. (2-tailed) & .093 \\
\hline
\end{tabular}

a. Wilcoxon Signed Ranks Test

b. Based on negative ranks.

Source: The researcher's data analysis

\section{Comparison between the EG's pre-test and post-test}

The statistics of Wilcoxon Signed Ranks Test (Table 4) indicate that the significance value is .000 , which is less than .05; therefore, the difference between the pre-test and post-test scores in the EG there is statistically significant. As a result, the median score of the post-test $(M d n=5.6)$ is significantly greater than the median score of the pre-test $(M d n=3.6)$ (see Table $1)$.

\section{Table 4}

Wilcoxon Signed Ranks Test for the EG before and after treatment

Ranks

\begin{tabular}{|ll|c|c|c|}
\hline & N & Mean Rank & Sum of Ranks \\
\hline Posttest - Pretest & Negative Ranks & $8^{\mathrm{a}}$ & 10.44 & 83.50 \\
& Positive Ranks & $26^{\mathrm{b}}$ & 19.67 & 511.50 \\
& Ties & $2^{\mathrm{c}}$ & & \\
& Total & 36 & & \\
\hline
\end{tabular}
a. Posttest $<$ Pretest
b. Posttest > Pretest
c. Posttest $=$ Pretest 


\section{Test Statistics}

\begin{tabular}{|l|c|}
\hline & Posttest - Pretest \\
\hline$Z$ & $-3.667^{\mathrm{b}}$ \\
\hline Asymp. Sig. (2-tailed) & .000 \\
\hline
\end{tabular}

a. Wilcoxon Signed Ranks Test

b. Based on negative ranks.

Source: The researcher's data analysis

\section{Comparison between the CG's and EG's post-test}

The results of Mann-Whitney Test in Table 5 shows that the significance value is .041 which is less than .05; so the difference in the median scores of the CG $(M d n=4.8)$ and the EG $(M d n=5.6)$ (see Table 1) on the post-test is statistically significant.

\section{Table 5}

Mann-Whitney U test for the scores of the CG and EG's post-test

Ranks

\begin{tabular}{|l|c|c|c|c|}
\hline & Group & N & Mean Rank & Sum of Ranks \\
\hline Posttest & CG & 35 & 30.94 & 1083.00 \\
& EG & 36 & 40.92 & 1473.00 \\
& Total & 71 & & \\
\hline
\end{tabular}

\section{Test Statistics}

\begin{tabular}{|l|c|}
\hline & Posttest \\
\hline Mann-Whitney U & 453.000 \\
Wilcoxon W & 1083.000 \\
Z & -2.044 \\
Asymp. Sig. (2-tailed) & .041 \\
\hline
\end{tabular}

a. Grouping Variable: Group

Source: The researcher's data analysis

\subsection{Students' attitudes to using videos in listening learning}

As mentioned in Section 3.3, the questionnaire was categorized into three 3 scales in accordance with 3 components of attitudes: Scale 1 (4 items) about students' feelings on using videos in listening learning, Scale 2 ( 7 items) about students' beliefs about using videos in listening learning, and Scale 3 (3 items) about students' behavior tendencies towards listening learning. Therefore, the total score for each scale was calculated by adding up the scores of all the items left on the scale after checking its internal consistency.

Table 6 shows that the students had positive feelings about using videos in their listening learning $(M=4.34, S D=.40)$, they had positive beliefs about using videos in listening learning $(M=4.31, S D=.45)$, and they had positive behavior tendencies towards listening learning $(M=3.98, S D=1.17)$. 


\section{Table 6}

Descriptive statistics of total score of 3 scales

\begin{tabular}{|l|c|c|c|c|c|}
\hline & N & Minimum & Maximum & Mean & Std. Deviation \\
\hline Scale 1 & 36 & 3.75 & 5.00 & 4.34 & .40 \\
\hline Scale 2 & 36 & 3.60 & 5.00 & 4.31 & .45 \\
\hline Scale 3 & 36 & 3.00 & 5.00 & 3.98 & .39 \\
\hline Valid N (listwise) & 36 & & & & \\
\hline
\end{tabular}

Source: The researcher's data analysis

\subsection{Discussion}

The findings show that learning listening with videos positively influenced students' listening performance. The current findings go in line with those of other studies, for example, Herron et al. (2006), Chiang (1996), Oddone (2011), Mesri (2011), Woottipong (2014), and Nguyen (2012). The positive effects of using videos on the students' listening comprehension could be explained by visual elements. First, visual elements facilitated the students' listening comprehension. Due to visual clues, the students could guess the meanings of new words and understand main ideas more easily than by listening to audio materials. Second, visuals clues created the students' positive attitudes. Visual clues interested and attracted the students, and they created relaxing environment which made the students like to learn. As the students found that learning listening was not too difficult, and learning listening was also interesting, they could have become more attentive to the listening lessons, they could have learned listening harder in class or could have even done more listening practice outside classes, especially listening with videos. As a result, most of them could improve their listening skills.

\section{Conclusion}

The current study shows the positive influences of using videos on elementary students' listening comprehension and their positive attitudes towards using videos in listening learning. The study would be able to help students learn listening more effectively with videos, and it can provide references for further research in the same field. However, it revealed some limitations. First, because of the conditions of the research site, a quasi-experiment design with non-random sampling and non-random assignment was used. Second, the experimental course just lasted for a pretty short period of time (10 weeks). Moreover, with a limited study scope, the experimental materials consisted of only one type that is TV documentaries while there are a lot of others like films, songs, dialogues, etc.

Therefore, the researcher respects to see further research conducted in this field in other contexts and conditions. First, further research should be undertaken under the format of a true experiment in which random sampling and random assignment are used to increase its generalizability and internal validity. Second, further research should last longer. Finally, further research should investigate the impact of using other types of educational videos, even truly authentic videos. 
In conclusion, the current study was designed to investigate the impact of using videos on the students' listening comprehension and explore students' attitudes towards using videos in listening learning in Foreign Languages and Informatics Center of PPC II. The findings imply that using videos had positive influences on the students' listening comprehension, and students had positive attitudes towards using videos in listening learning. Therefore, using videos in listening learning is worthy due consideration.

\section{References}

Bacon, S., \& Finnemann, M. (1990). A study of attitudes, motives, and strategies of university of foreign language students and their exposition to authentic aural and written input. The Morden Language Journal, 74(4), 459-573.

Baron, R. A., \& Byrne, D. (1984). Social psychology understanding human interaction. Boston, MA: Allyn \& Bacon.

Brownell, J. (2016). Listening: Attitudes, principles, and skills. Boston, MA: Routledge.

Cambridge University Press. (2003). Key English test 1. Cambridge, UK: Cambridge University Press.

Canning-Wilson, C. (2000). Practice Aspects of using video in the foreign language classroom. Retrieved July 6, 2016, from The Internet TESL Journal webiste: http://itestlj.org/articles/ canningvideo.html.

Chiang, H. L. (1996). Students introducing their favorite English movies. Paper presented at the 12th Conference on English Teaching and Learning in the Republic of China, China.

Chung, U. K. (1994). The effect of audio, a single picture, multiple pictures or videos in second language listening comprehention. (Unpublished doctoral dissertation). The University of Illinois at Urbana-Champagne, Champaign, IL.

Creswell, J. W. (2012). Educational research: Planning, conducting, and evaluating quantitative and qualitative research. Boston, MA: Pearson.

Cruse, E. (2007). Using educational video in the classroom: Theory, research and practice. Wynnewood, PA: Library Video Company.

Denning, D. (2010). Video in theory and practice: Issues for classroom use and teacher video evaluation. Retrieved July 24, 2017, from Grammar Movie: http://videosgrammar.blogspot.com/2010/05/antecedentes.html

Ellis, R. (2015). Understanding second language acquisition (2nd ed.). Oxford Applied linguistics. Oxford, UK: Oxford University Press.

Frommer, J. (1989). Listening, looking, and learning with MacLang. Calico Journal, 6(4), 5171.

Gardner, R. C., \& Lambert, W. E. (1972). Attitudes and motivation in second language learning. Rowley, MA: Newbury House Publisher.

Hammer, J. (1991). The practice of English language teaching. London, UK: Longman.

Harmer, J. (2007). The practice of English language teaching (4th ed.). England, UK: Longman. 
Herron, C., York, H., Corrie, C., \& Cole, S. (2006). A comparison study of the effects of a story-based video instructional package versus a text-based instructional package in the intermediate-level foreign language classroom. Calico Journal, 23(2), 281-307.

Hughes, J., Stephenson, H., \& Dumette, P. (2016). Life A1-A2. Singapore: National Geographic Leaning - Cengage.

Ilin, G., Kutlu, O., \& Kutluay, A. (2013). An action research: Using videos for teaching grammar in an ESP class. Procedure-Social and Behavioral Sciences, 70, 272-281.

Intajuck, Y. (2010). Maximizing the utilization of video in the EFL/ESL classroom. Retrieved July 23, 2017, from http://citeseerx.ist.psu.edu/viewdoc/download?doi=10.1.1.602.2109 \&rep=rep $1 \&$ type $=$ pdf

Ismaili, M. (2013). The effectiveness of using movies in the EFL classroom - A study conducted at South East European University. Academic Journal of Interdisciplinary Studies, 2(4), 121-132.

Jafari, S. M. (2009). On the relationship between listening comprehension motivation and listening comprehension among the Iranian EFL learners. Retrieved July 30, 2017, from Translation Directory website: http://www.translationdirectory.com/articles/article1994.php

Karahan, F. (2007). Language attitudes of Turkish students towards the English language and its use in Turkish context. Journal of Arts and Science Say, 73-87.

Mesri, F. (2011). Using different presentations of pictures and video cues and Iranian EFL learners' listening comprehension. Modern Journal of Language Teaching Methods, 1(3), $132-142$.

Nguyen, T. T. (2012). Using audiovisual material to improve students' listening comprehension at Kiengiang Technology-Economics College-Thesis of MA (TESOL). Ho Chi Minh, Vietnam: Ho Chi Minh City Open University.

Nunan, D. (1999). Second language teaching and learning. Boston, MA: Heinle \& Heinle.

Oddone, C. (2011). Using videos from YouTube and websites in the CLIL classroom. STUDIES ABOUT LANGUAGES, 18, 105-109.

Roh, J. (2011). The development of the cultural video project and its impacts on Korean learning. The Korean Language Learning, 16, 73-100.

Rumelhart, D. (1977). Understanding and summarizing brief stories. In D. L. Samuels (Ed.), Basic process in reading comprehension (pp. 33-58). Hillsdale, NJ: Lawrence Erlbaum Associates.

Schmitt, N. (2010). An introduction to applied linguistics (2nd ed.). London, UK: Holder Education.

Stohlman, K. (2009). The biggest mistakes teachers make using video in the classroom. Retrieved July 23, 2017, from http://citeseerx.ist.psu.edu/viewdoc/download? doi=10.1.1.602.2109\&rep=rep1\&type $=$ pdf

Woottipong, K. (2014). Effect of using videos materials in the teaching of listening skills for university students. International Journal of Linguistics, 6(4), 200-212. 